\title{
Research of Stability of Swine's Cryoliophilized Xenoderma Tablets
}

Ravliv Yuliia Andriivna*, Pokotylo Olena Olexandrivna

Horbachevsky Ternopil National Medical University, Ukraine

*Corresponding author: Ravliv Yuliia Andriivna, Horbachevsky Ternopil National Medical University, Ukraine

Received date: March 13, 2020; Accepted date: April 15, 2020; published date: May 05, 2020

Citation: Ravliv Yuliia Andriivna, Pokotylo Olena Olexandrivna, Dermatomyositis-Like Multicentric Reticulohistiocytosis: A Clinical Clue to Verify Underlying Malignancy. J Clinical Research and Reports, 4(1); DOI:10.31579/2690-1919/072

Copyright: (C) 2020 Ravliv Yuliia Andriivna. This is an open access article distributed under the Creative Commons Attribution License, which permits unrestricted use, distribution, and reproduction in any medium, provided the original work is properly cited.

\section{Abstract}

The aim of this research was to study of stability of the basic physico-chemical and pharmaco-technological indexes of quality (appearance, average mass, homogeneity of mass, resistance to crushing, erosion, decomposition, identification and quantitative determination of amino acids) obtained samples of tablets based on the swine's cryoliophilized xenoderma with lecithin and without it. The results of study samples of drugs fit into acceptable standards and show the stability of the main quality indicators during three years of storage at a temperature $(8-10)^{\circ} \mathrm{C}$ in a tightly closed containers in a place protected from light.

Keywords: powder of swine's cryolophilized xenoderma, lecithin, pills, stability, xenodermic implants, ulcerative processes, wound healing activity.

\section{Introduction}

Nowadays the pharmaceutical market offers a number of medicines with immunostimulatory and immunoprotective pharmacological activity. $[3,16]$ In the complex treatment of this pathology, in addition to etiotropic therapy, the polypropylenic drugs of symptomatic action are widely used. The majority of these drugs contain active pharmaceutical ingredients (APhIs) of chemical origin. However, the global pharmaceutical market is increasing the demand for drugs of natural origin, in particular for organopreparations. [16] The urgent necessity in creating effective natural medicines, from natural raw materials, for prevention and treatment of various diseases is primarily due to the negative environmental effect and stress factors influence on the human health and employability.

Organopreparations complement the deficiency of cellular biomolecules, eliminate various "cellular defects" at the cellular level, due to the effect of organotropy improve the processes of physiological regeneration in the appropriate organs of the patient. This leads to a normal renovation of organs and tissues and theirs physiological functions.

So, a group of Ukrainian scientists under the leadership of prof. V.V. Bihuniak (LLC "Institute of Biomedical Technologies", Ternopil) has developed a dietary supplement "Xenoderm", which contains natural complexes of peptides, amino acids, micro-and macro elements, nucleotides, growth factors, etc. [13,14] Such dietary supplement cause a wide range of pharmacological activity, accordingly: antihistamines, antiallergic, membrane-protector, anti-toxic and antimicrobial effects in allergic diseases; stimulate the effective healing of wounds and ulcers; improves the functioning of the digestive system; has the properties of a natural adsorbent. [2,6,7]

Considering the deficit of the natural origin preparations of the above mentioned action in the modern pharmaceutical market, it was necessary to conduct the pharmaceutical development and basic pharmaco-technological research, in particular, studying the stability of swine's cryoliophilized xenoderma pills.

Materials and Methods
Under the conditions of organoxenodermotransplants' manufacture, which are included in the state register of medical products of Ukraine and are widely used in burns department, it has been developed and tested a technology of the grinded substrate of swine's cryoliophilized xenoderma as a substance for the manufacture tablets for oral ingestion [TC U 15.8-35578106 -001: 2011] [14]. Grinded swine's cryoliophilized xenoderma powder are packed in polyethylene bags (Fig. 1.).

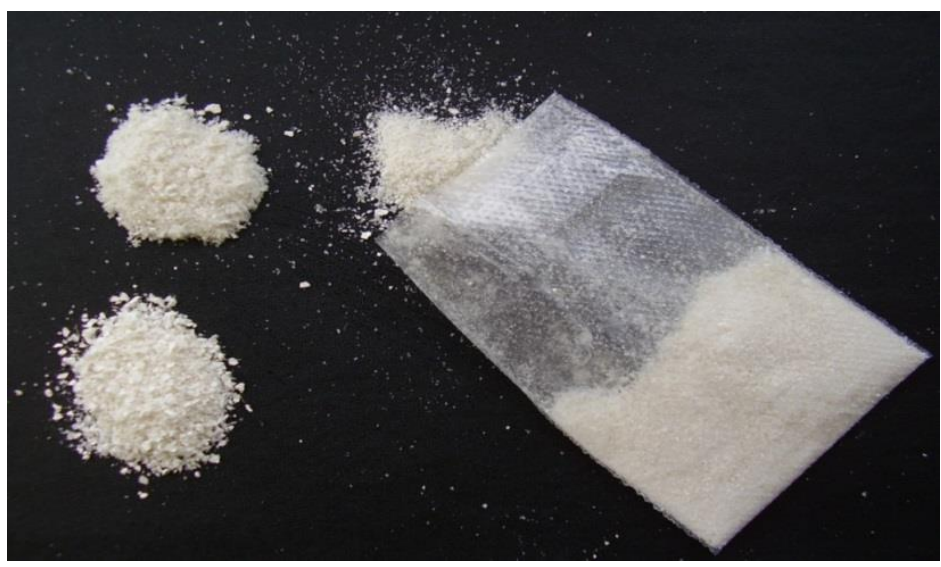

Fig. 1. View of grinded swine's cryoliophilized xenoderma powder

It was used as an active substance a dry amorphous, largegranulated, hygroscopic powder of swine's cryoliophilized xenoderma, gray color with separate yellow-brown different shapes particles for developing the composition and technology of the tablets. In order to select the excipients, it was established appropriate pharmacotechnological research of the tablets and were determined the relationship between the quantitative pharmaceutical factors. [10] This way, for the first time, it were proposed the composition and technology of tablets based on the swine's cryoliophilized xenoderma (Fig. 2) and composition and technology of tablets based on swine's cryoliophilized xenoderma with lecithin (Fig. 3) that were the subject of our stability research. 


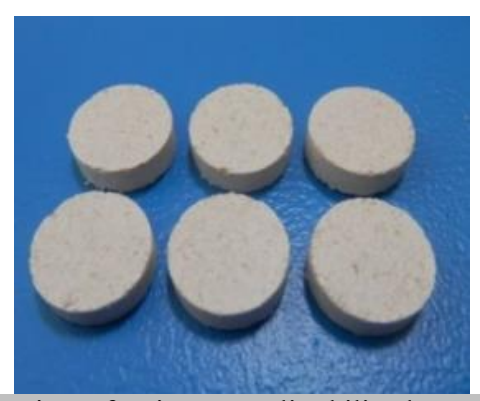

Fig. 2. View of swine's cryoliophilized xenoderma tablets

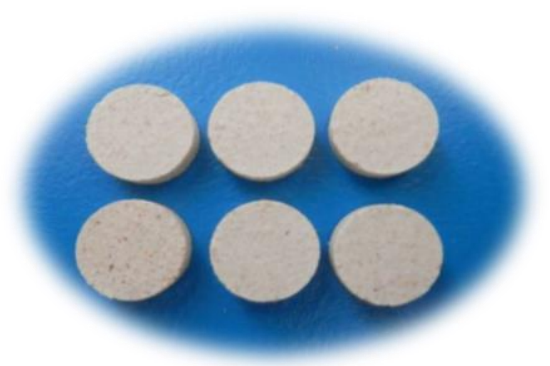

Fig. 3. View of swine's cryoliophilized xenoderma tablets with lecithin
It has been developed the project of operating practices of technology and quality control methods for the tablets which have been tested in the industrial conditions at Farmak IL.

Stability tests were carried out with tablets based on swine's cryoliophilized xenoderma with lecithin and without it in order to obtain the results about medicines' quality changes under the influence of various environmental factors, as well as to establish the recommended storage conditions for the samples. $[1,5,8,10]$

Preliminary, samples of tablets were packed in polypropylene plastic containers in $100 \mathrm{pcs} / \mathrm{pack}$ and stored in a dark place at a temperature of $(8-10){ }^{\circ} \mathrm{C}$, so far as lecithin is capable of oxidation and the loss of valuable properties of the swine's cryoliophilized xenoderma at a high temperature. Stability research of two types of tablets (with lecithin and without) were determined for 2 years, the results of the basic pharmaco-technological parameters were recorded every 3 months in the first year and every 6 months in the second year of the test. The samples of the tablets were examined in appearance, average weight, mass homogeneity, crushing resistance, friability of tablets, disintegration, quantitative content of amino acids in accordance with the requirements of the SPhU. [15] The results of the research of the basic pharmacological and technological parameters of the tablets are shown in tables 1, 2.

We used the computer program in Microsoft Excel for automate statistical calculations.

\section{Results and Discussion}

Storage conditions have a great effect on the stability of medicinal substances in tablets and their physico-chemical parameters. It's known the tablets lose moisture in a dry air that is one of the main reasons for their cementation and complete loss of ability to disintegration. At high humidity, the stability of the tablets usually decreases, while the time of disintegration can increase or decrease. [1,9] Rise of air temperature and the solar activity also has a negative effect on the quality of tablets. Therefore, the tablets are stored at room temperature in a dry, lightprotected place. [11]

Stability testing should include studies of characteristics of a finished product that are subject to changes in storage and may affect quality, safety and / or efficacy. It is necessary to investigate (depending on the specific situation) physical, chemical, biological and microbiological properties. $[4,8,12]$ Thus, research the stability of medicines is an additional source for the development and improvement of requirements that determine the quality of pharmaceuticals. [5]

General approaches to the stability's study have been applied for organ preparations as well. However, these products have a number of distinct features, which implies the existence of a carefully designed research program that confirms stability over the proposed shelf life. For this category of products where the active substance is usually biologically active substances, the preservation of the molecular structure and biological activity, accordingly, depends on the interactions due both to non-covalent and covalent bonds. This determines their increased sensitivity to such environmental factors as temperature change, the effect of oxidation, light, ionic composition, and so on. [4,17] In order to storage the biological activity of the tablets and to prevent their disintegration, strictly limited storage conditions are usually used.

In our case, the tablets' samples were stored at conditions consistent with long-term stability studies.

\begin{tabular}{|c|c|c|c|c|c|c|c|c|c|}
\hline \multirow[b]{2}{*}{ Test } & \multirow[b]{2}{*}{ Tolerance limits } & \multicolumn{8}{|c|}{ Results of test } \\
\hline & & Initial & 3 month & 6 month & 9 month & $\begin{array}{c}12 \\
\text { month }\end{array}$ & 18 month & 24 month & $\begin{array}{c}36 \\
\text { month }\end{array}$ \\
\hline Description & $\begin{array}{c}\text { Flat cylindrical shape } \\
\text { tablets with a ridge } \\
\text { and a facet, diameter } \\
14 \mathrm{~mm}\end{array}$ & Satisfy & BSatisfy & Satisfy & Satisfy & Satisfy & Satisfy & Satisfy & Satisfy \\
\hline $\begin{array}{l}\text { Identification } \\
\text { Aminoacids in } \\
\text { hydrolyzate }\end{array}$ & $\begin{array}{c}\text { In the electronic } \\
\text { absorption spectrum } \\
\text { of the test solution in } \\
\text { the range } 300- \\
700 \mathrm{~nm} \text {, two } \\
\text { absorption maxima } \\
\text { should be observed } \\
\text { at } 400 \pm 2 \mathrm{~nm} \text { and } \\
570 \pm 2 \mathrm{~nm} \text {. }\end{array}$ & Satisfy & Satisfy & Satisfy & Satisfy & Satisfy & Satisfy & Satisfy & Satisfy \\
\hline Average mass & From 0,76 г to 0,84 & $\begin{array}{c}0,805 \pm \\
0,014\end{array}$ & $0,805 \pm 0,009$ & $\begin{array}{c}0,803 \pm \\
0,013\end{array}$ & $0,803 \pm 0,009$ & $\begin{array}{c}0,802 \pm \\
0,010\end{array}$ & $0,802 \pm 0,012$ & $0,800 \pm 0,008$ & $\begin{array}{c}0,799 \pm \\
0,013\end{array}$ \\
\hline
\end{tabular}




\begin{tabular}{|c|c|c|c|c|c|c|c|c|c|}
\hline $\begin{array}{c}\text { Homogenous of } \\
\text { mass }\end{array}$ & Not more than $5 \%$ & Satisfy & Satisfy & Satisfy & Satisfy & Satisfy & Satisfy & Satisfy & Satisfy \\
\hline Disintegration & $\begin{array}{l}\text { Not more than } \\
15 \mathrm{~min}\end{array}$ & Satisfy & Satisfy & Satisfy & Satisfy & Satisfy & Satisfy & Satisfy & Satisfy \\
\hline $\begin{array}{l}\text { Quantitative test } \\
\text { Вміст амінокислот } \\
\text { Content of } \\
\text { aminoacids }\end{array}$ & $\begin{array}{c}\text { From } 0,476 \text { to } \\
0,644 \mathrm{mg}\end{array}$ & $\begin{array}{c}0,585 \pm \\
0,021\end{array}$ & $0,587 \pm 0,029$ & $\begin{array}{c}0,590 \pm \\
0,028\end{array}$ & $0,584 \pm 0,025$ & $\begin{array}{c}0,581 \pm \\
0,026\end{array}$ & $0,580 \pm 0,028$ & $0,583 \pm 0,029$ & $\begin{array}{c}0,582 \pm \\
0,027\end{array}$ \\
\hline
\end{tabular}

Table 1:The results of stability research of samples of tablets based on the swine's cryoliophilized xenoderma $0.4 \mathrm{~g}$ during storage at a temperature of $(9 \pm 1)^{\circ} \mathrm{C}$, humidity $(60 \pm 5) \%(\mathrm{n}=5 ; \mathrm{p} \leq 0.05)$

\begin{tabular}{|c|c|c|c|c|c|c|c|c|c|}
\hline \multirow{2}{*}{ Test } & \multirow{2}{*}{ Tolerance limits } & \multicolumn{8}{|c|}{ Results of test } \\
\hline & & Initial & 3 month & month & month & $\begin{array}{c}12 \\
\text { month }\end{array}$ & $\begin{array}{c}18 \\
\text { month }\end{array}$ & 24 month & 36 month \\
\hline Description & $\begin{array}{c}\text { Flat cylindrical shape } \\
\text { tablets with a ridge } \\
\text { and a facet, diameter } \\
14 \mathrm{~mm}\end{array}$ & $\begin{array}{c}\text { Відповідає } \\
\text { Satisfy }\end{array}$ & $\begin{array}{c}\text { Відповідає } \\
\text { Satisfy }\end{array}$ & $\begin{array}{c}\text { Відповідає } \\
\text { Satisfy }\end{array}$ & $\begin{array}{c}\text { Відповідає } \\
\text { Satisfy }\end{array}$ & $\begin{array}{l}\text { Відпові } \\
\text { дає } \\
\text { Satisfy }\end{array}$ & $\begin{array}{c}\text { Відповід } \\
\text { aє } \\
\text { Satisfy }\end{array}$ & $\begin{array}{c}\text { Відповідає } \\
\text { Satisfy }\end{array}$ & $\begin{array}{c}\text { Відповідає } \\
\text { Satisfy }\end{array}$ \\
\hline \multirow[b]{2}{*}{$\begin{array}{l}\text { Aminoacids in } \\
\text { hydrolyzate }\end{array}$} & $\begin{array}{l}\text { In the electronic } \\
\text { absorption spectrum } \\
\text { of the test solution in } \\
\text { the range } 300-700 \mathrm{~nm} \text {, } \\
\text { two absorption } \\
\text { maxima should be } \\
\text { observed at } 400 \pm \\
2 \mathrm{~nm} \text { and } 570 \pm 2 \mathrm{~nm} \text {. }\end{array}$ & Satisfy & Satisfy & Satisfy & Satisfy & Satisfy & Satisfy & Satisfy & Satisfy \\
\hline & $\begin{array}{l}\text { The presence of clear } \\
\text { areas of blue-violet } \\
\text { color at the zone level } \\
\text { on the chromatogram } \\
\text { of a solution of LRC } \\
\text { lecithin of the same } \\
\text { color and intensity }\end{array}$ & Satisfy & Satisfy & Satisfy & Satisfy & Satisfy & Satisfy & Satisfy & Satisfy \\
\hline Average mass & From 0,76 to 0,84 & $\begin{array}{c}0,795 \pm \\
0,012\end{array}$ & $\begin{array}{c}0,789 \pm \\
0,011\end{array}$ & $\begin{array}{c}0,795 \pm \\
0,012\end{array}$ & $\begin{array}{c}0,800 \pm \\
0,013\end{array}$ & $\begin{array}{c}0,798 \pm \\
0,012\end{array}$ & $\begin{array}{c}0,795 \pm \\
0,011\end{array}$ & $\begin{array}{c}0,798 \pm \\
0,010\end{array}$ & $\begin{array}{c}0,792 \pm \\
0,013\end{array}$ \\
\hline $\begin{array}{l}\text { Homogenous } \\
\text { of mass }\end{array}$ & Not more than $5 \%$ & Satisfy & Satisfy & Satisfy & Satisfy & Satisfy & Satisfy & Satisfy & Satisfy \\
\hline Disintegration & Not more than $15 \mathrm{~min}$ & Satisfy & Satisfy & Satisfy & Satisfy & Satisfy & Satisfy & Satisfy & Satisfy \\
\hline $\begin{array}{l}\text { Quantitative } \\
\text { test } \\
\text { Content of } \\
\text { aminoacids }\end{array}$ & $\begin{array}{c}\text { Від } 0,476 \text { до } 0,644 \text { мг } \\
\text { From } 0,476 \text { to } \\
0,644 \mathrm{mg}\end{array}$ & $\begin{array}{c}0,585 \pm \\
0,021\end{array}$ & $\begin{array}{c}0,587 \pm \\
0,025\end{array}$ & $\begin{array}{c}0,590 \pm \\
0,029\end{array}$ & $\begin{array}{c}0,584 \pm \\
0,027\end{array}$ & $\begin{array}{c}0,581 \pm \\
0,025\end{array}$ & $\begin{array}{c}0,580 \pm \\
0,024\end{array}$ & $\begin{array}{c}0,583 \pm \\
0,030\end{array}$ & $\begin{array}{c}0,582 \pm \\
0,031\end{array}$ \\
\hline $\begin{array}{l}\text { The content of } \\
\text { lecithin in } \\
\text { terms of total } \\
\text { phosphorus }\end{array}$ & $\begin{array}{c}\text { Від } 0,816 \text { мг до } \\
1,104 \text { мг } \\
\text { From } 0,476 \text { to } \\
0,644 \mathrm{mg}\end{array}$ & $\begin{array}{c}0,965 \pm \\
0,075\end{array}$ & $\begin{array}{c}0,960 \pm \\
0,069\end{array}$ & $\begin{array}{c}0,958 \pm \\
0,079\end{array}$ & $\begin{array}{c}0,964 \pm \\
0,059\end{array}$ & $\begin{array}{c}0,959 \pm \\
0,070\end{array}$ & $\begin{array}{c}0,960 \pm \\
0,065\end{array}$ & $\begin{array}{c}0,962 \pm \\
0,063\end{array}$ & $\begin{array}{c}0,964 \pm \\
0,070\end{array}$ \\
\hline
\end{tabular}

Table 2: The results of stability research of samples of tablets based on the swine's cryoliophilized xenoderma with lecithin during storage at a temperature of $(9 \pm 1)^{\circ} \mathrm{C}$, humidity $(60 \pm 5) \%(n=5 ; p \leq 0.05)$

According to the presented data, during 36 months ( 3 years), no significant changes in the quality of the proposed tablets' samples are made that could affect the medicines' quality.

Tablets based on the swine's cryoliophilized xenoderma and based on the swine's cryoliophilized xenoderma with lecithin were stored at a temperature of $(8-10)^{\circ} \mathrm{C}$ and provide positive identification and quantitative tests. The quantitative content varies within the determination error. The results of tablets' samples research satisfy to established standards.
This way, the studied tablets were stable during storage throughout the observation period. The recommended shelf life of the proposed tablets is at least two years under following stored conditions: temperature - $(8-10)^{\circ} \mathrm{C}$ in tightly closed containers in a place protected from light.

\section{Conclusion}

1. In this study, the stability of the basic pharmaco-technological parameters of tablets based on the swine's cryoliophilized xenoderma 
with lecithin and without it under the storage conditions $\left((9 \pm 1)^{\circ} \mathrm{C}\right.$ at humidity $(60 \pm 5) \%)$ for three years was determined.

2. The studies showed that the shelf life of the tablets has been inverstigated: at least 2 years at a temperature of $(9 \pm 1)^{\circ} \mathrm{C}$ in tightly closed containers in a place protected from light at a humidity $(60 \pm 5) \%$.

\section{References}

1. Andriychuk Y. R. Study of the stability of chewing tablets with oat and quercetin extracts in the process of storage / Y. R. Andriychuk, L. L. Davtyan // Pharm. Journal. - 2015. - №. 2. - P. 20-23.

2. Bihuniak V.V. Biodegradable properties of xenodermictransplant of the secondary incision during plastic of sluggish wounds / V.V. Bihuniak, A.O. Kovalchuk, T. Romanyuk // Bulletin of scientific researches. - 2012. - №. 1. - P. 56 - 57.

3. Compendium OnLine [Electronic resource].

4. $\mathrm{CPMP} / \mathrm{ICH} / 138 / 95$ (ICH Topic Q 5C) «Quality of Biotechnological Products : Stability Testing of Biotechnological / Biological Products»

5. CT-NMOSU 42-6.0: 2014. Medicines. Preclinical safety studies as a basis for human clinical trial and drug registration (ICH M3 (R 2)) / State Enterprise "State. expert. Center of the Ministry of Health of Ukraine ". - Kyiv: Ministry of Health of Ukraine, 2014. - 45 p. - (Settlement).

6. Guda N.V. Freeze-dried xenodermic implants in the treatment of patients with burns [Electronic resource] / N.V. Huda, T.V.Bihuniak, Yu.A. Ravliv // Materials of the All-Ukrainian scientific and practical internet conference with the participation of international specialists "Social Pharmacy in Ukraine: State, Problems, Prospects", April 3 - 8, 2013 - Kharkiv, 2013. - Mode of access: http://socpharm.nuph.edu.ua/files/2013/04/12T2-GBR .pdf

7. Guda N.V. The content of amino acids and trace elements in cryoliophilized xenoderma as an indicator of its biological activity / N.V. Guda, A.V. Tsimbalyuk // Medical Chemistry. - 2012. - №. 1. - P. 70 - 72.

8. Guideline 42 -3.3: 2004. Medicines. Stability / Development Tests. : V. Georgiyevsky, M. Lyapunov, A. Bezugla [and others];
State sciences center doctor funds. - Kyiv: Ministry of Health of Ukraine, 2004. - 60 p. - (Quality guidelines).

9. Laila H. Emara, Ahmed A. El-Ashmawy, and Nesrin F. Taha. Stability and bioavailability of diltiazem/polyethylene oxide matrix tablets," Pharmaceutical Development and Technology 2017; pp. 1-10.

10. Manual 42 -3.4: 2004. Medicines. Production of finished pharmaceuticals / development. : M. Lyapunov, V. Georgievsky, A. Bezugla [and others]; State sciences center doctor funds (State Enterprise "DNTSLZ"). - Kyiv: Ministry of Health of Ukraine, 2004. - 11 p. - (Quality guidelines).

11. Narasaiah V. L., Karthik Kumar T., Srinivas D. et al. Stability studies of formulated controlled release aceclofenac tablets. Int. J. Chem. Sci. 2010; 8(1): 405-414.

12. Oliveira P. R., Mendes C., Klein L. et al. Formulation Development and Stability Studies of Norfloxacin ExtendedRelease Matrix Tablets. BioMed Research International vol. 2013: Article ID 716736: 9 pages.

13. Pat. 10737 Ukraine, IPC A $01 \mathrm{~N} \mathrm{1/2.} \mathrm{Method} \mathrm{of} \mathrm{manufacturing}$ xenoderma transplants / V.V.Bihuniak, P.I.Luch'ko; Applicant and patent holder Ternopil State Medical University I. Ya. Gorbachevsky. - №. 95041596; stated. April 10, 1994; has published Dec 25, 1996, Bul. No. 4

14. Pat. 66353 Ukraine, IPC A $01 \mathrm{~N} 1 / 02$. A method of manufacturing xenografts / V.V.Bihuniak, N.V.Bihuniak; Applicant and patent holder Ternopil State Medical University I. Ya. Gorbachevsky. №. 99084730; stated. 19.08.99; has published May 17, 04, Bull. №. 5

15. State Pharmacopoeia of Ukraine / State Enterprise "Ukrainian Scientific Pharmacopoeial Center for Quality of Medicines". 1-st view. - Supplement 3. -Х.: ДП "Ukrainian ScientificPharmacopoeial Center for Quality of Medicinal Products", 2009 $-280 \mathrm{p}$.

16. The main trends of development of the pharmaceutical market of Ukraine in pharmacotherapeutical groups / A.O. Drozdova, Z.V. Malenka, I.O. Vlasenko [and others]. - Kyiv: Education of Ukraine, 2015. - $130 \mathrm{p}$.

17. World Health Organization, Annex 2: Stability Testing of Active Pharmaceutical Ingredients and Finished Pharmaceutical Products, vol. 953 of WHO Technical Report Series, 2009.
This work is licensed under Creative Commons Attribution 4.0 License

To Submit Your Article Click Here: Submit Manuscript

DOI: $10.31579 / 2690-1919 / 072$
Ready to submit your research? Choose Auctores and benefit from:

$$
\begin{aligned}
& \text { * fast, convenient online submission } \\
& \text { rigorous peer review by experienced research in your field } \\
& \text { *apid publication on acceptance } \\
& \text { * unthors retain copyrights } \\
& \text { * immediate, unrestricted online access }
\end{aligned}
$$

At Auctores, research is always in progress.

Learn more www.auctoresonline.org/journals/journal-of-clinical-researchand-reports 